\title{
Cultivation of Angelica archangelica Linn.: evaluation for economical viability at two different climatic conditions
}

\author{
Rajiv K. VASHISTHA ${ }^{1}$, B.P. NAUTIYAL ${ }^{2}$ and M.C. NAUTIYAL ${ }^{1 *}$ \\ ${ }^{I}$ High Altitude Plant Physiology Research Centre (HAPPRC), HNB Garhwal University, Srinagar Garhwal, \\ Uttarakhand, India. \\ ${ }^{2}$ Department of HAMP, School of Earth Sciences and Natural, Resources Management, Mizoram University, \\ Aizawl, India. \\ *Corresponding author, E-mail: mcnautiyal@gmail.com
}

\begin{abstract}
Cultivation of an important sub alpine-alpine medicinal and aromatic herb, Angelica archangelica Linn. (Apiaceae), was carried out at two different climatic zone at $2200 \mathrm{~m}$ asl (Pothivasa, PV) and $3600 \mathrm{~m}$ asl (Tungnath, TN) altitudes in Garhwal, North west Himalaya, India. These altitudes represent temperate and alpine region of the Himalaya. Since the species has a very few wild populations, cultivation of the species is recommended for its medicinal use. After the establishment of sufficient quantity of seedlings, they were transplanted in both sites at the age of two, three and four months for the comparative accounts on survival, growth and yield and, to test the appropriate age of seedlings for transplantation and climatic suitability for cultivation of the species. Organic cultivation protocol was adopted by using different farm yard manure (FYM) as treatments. Yield was minimum in youngest seedlings (two months old ) transplanted at TN in ordinary alpine soil (control) and maximum under polyhouse beds at PV after three years of growth. Observations on yield at different climatic zone revealed that it was maximum in PV (temperate site) as compared to alpine site (natural site) in all treatments. Seedlings of different age also had better survival, growth and yield at the temperate site though; two months old seedlings after transplantation had comparatively slow growth and yield than those of three and four months seedlings. These observations clearly suggested that temperate region $(2200 \mathrm{~m})$ is suitable for cultivation of A. archangelica. Addition of manure (leaf litter in particular) and polyhouse cultivation further improved the yield. Economical viability of the cultivation was also observed and presented here.

(c) 2008 International Formulae Group. All rights reserved.
\end{abstract}

Keywords: Seedlings, economic yield, profit, observations, polyhouse.

\section{INTRODUCTION}

Angelica archangelica Linn. (European angelica or wild parsnip) is native to Europe including Austria, Belgium, Germany, UK and Poland. It is described as "Gandrayan Bhaid" in Traditional System of Medicine (Ayurveda) and "Rickhchoru" (means pseudo angelica) in Garhwal, North-West Himalaya. It is an aromatic, stout, perennial herb, 60-200 $\mathrm{cm}$ in height, and distributed near the water channels in sub alpine-alpine regions of Kashmir (1000-3900 m), Uttarakhand between an altitudes of $2600 \mathrm{~m}-3900 \mathrm{~m}$
(Nautiyal and Nautiyal, 2004; Vashistha et al., 2006) and also reported from Sikkim (3000$3300 \mathrm{~m})$ in North east Himalaya having fragmented habitats. Angelica archangelica has a long folk-history of use as a medicinal herb, in particular for the treatment of digestive disorders and blood circulation related problems (Grieve, 1984; Chevallier, 1996). This plant is also an important ingredient of folk medicine as a remedy for nervous headache, fever, skin rashes, wounds, rheumatism, and toothaches. It is believed to possess saintly healing power. It can also be 
used as an antiseptic, expectorant, emmenagogue and a diuretic (Anonymous, 1985). The roots from Kashmir yield five furocoumarins. An isocoumarin, angelicain (mp $\left.194{ }^{\circ} \mathrm{C}\right)$, a new flavonone, archangelenone (mp $148{ }^{\circ} \mathrm{C}$; yield $0.005 \%$ ) and diprenyl maringenin are also present. The coumarins are reported to be useful in curing leucoderma. A. archangelica revealed the presence of various types of secondary metabolites, predominantly 2-4 furanocoumarins (Anonymous, 1985; Sarker et al., 2004). In Europe, the essential oil from the plant is used in liquors, dental preparations and in high grade perfumery to impart a musky note leading into increasing global market demands. Above all, rediscovery of the value of traditional systems of health care and medicines, and potential of new drug discoveries from biological resources and employment options with market potential are viewed with great hope for sustainable development (Nautiyal et al., 2005).

Recently, Vashistha et al. (2006) reported the species as critically endangered for North west Himalaya, due to man induced changes in the form of habitat disturbances through over and heavy exploitation of plants in high altitude areas of Himalaya, the original habitat is degraded and leading to small size of population and suggested immediate remedial measures for the conservation of natural populations. The most effective way of protecting rare and endangered species would be through their protection in the natural habitats. Since medicinal plants are vital to the economy of the people settled in high altitude Himalayan belt, it becomes obligatory to initiate steps for domestication and cultivation of these species (Nautiyal et al., 2001) including $A$. archangelica. The cultivation of this species will fulfil the demand of the market at comparatively lower price and thus ease the pressure on their natural habitats. Furthermore, medicinal and aromatic plant (MAP) cultivation may be a better option for the economic uplift of local inhabitants as most of the traditional crops grown in the area are not viable due to low market value. In present scenario, cultivation of medicinal plants can be viewed as a possible bridge between sustainable economic development, affordable health care and conservation of imperative biodiversity. Various aspects of the species including taxonomy, general distribution, uses and phytochemical properties (Gaur, 1999; Phillips and Foy, 1990) are well known now. However, till date cultivation aspects of $A$. archangelica is not taken into account. Since it is sub alpinealpine species and it is not possible to initiate cultivation there due to short growth period and climatic adversity (Nautiyal et al., 2001) and more importantly, no human settlement, we also attempted to domesticate the species comparatively at lower altitude, i.e. $2200 \mathrm{~m}$, near the vicinity of the human settlement. Considering these facts, present communication addresses appropriate age of seedlings for transplantation, production and economical viability of $A$. archangelica by using organic farming protocol at natural site (alpine) and temperate site

\section{MATERIALS AND METHODS}

Cultivation trials of $A$. archangelica were conducted at two different climatic zone, i.e. Tungnath (TN) an alpine zone $(3600 \mathrm{~m}$ asl) located between $30^{\circ} 14^{\prime} \mathrm{N}$ Lat. and $79^{\circ} 13^{\prime} \mathrm{E}$ Long. and Pothivasa (PV) situated in temperate zone (2200 $\mathrm{m}$ asl) between $30^{\circ} 28^{\prime} \mathrm{N}$ Lat. and $79^{\circ} 16^{\prime} \mathrm{E}$ Long. in Rudraprayag district of Garhwal, Uttarakhand Himalaya, India. In alpine zone institute High Altitude Plant Physiology Research Centre (HAPPRC) has alpine garden having the germplasm of more than 100 species and experience heavy snow fall during winter with only 4-6 months of growth period. The temperate site (PV) was established by the institute High Altitude Plant Physiology Research Centre (HAPPRC) after multi-locational observations on survival and growth of alpine plants for the domestication near the vicinity of villages and was found the best. Presently, this site is serving as germplasm repository of many alpine medicinal plants for the cultivation purpose (Nautiyal et al., 2001and 2003; Nautiyal and Nautiyal, 2004). The soil pH varied between 3.29- 4.49 in TN and 4.67 5.01 in PV site. Similarly, soil organic carbon content was $3.83-4.08 \%$ for TN and $1.0-$ $1.23 \%$ for $\mathrm{PV}$, nitrogen content $0.02-0.16 \%$ for TN and $0.04-0.23 \%$ for PV while potassium and phosphorus content was very low in the soil of both sites (Vashistha et al., 2007). 


\section{Climatological data of study areas}

In Pothivasa (PV) temperature ranged between $6.7-27.7{ }^{\circ} \mathrm{C}$ wherein Tungnath $(\mathrm{TN})$ temperature ranged between $5.2-21.8{ }^{\circ} \mathrm{C}$. In PV rainfall ranged between 99.2-1401.2 (mm) wherein TN rainfall ranged between 139.811550.31 (mm). Humidity (\%) was found higher in $\mathrm{TN}(78.80 \%)$ in comparaison to $\mathrm{PV}$ nursery (Figure 1-3).

Experimental beds of $1 \mathrm{~m}^{2}$ area were prepared by digging the land three-four times using replication method with three replicates of each treatment at both sites. Beds were raised $(30 \mathrm{~cm}$ from the land surface) to prevent water logging during rainy season. Buffalo dung manure (BM) is commonly available in these sites as large herd of buffalo reaches every year in alpine zone during the summer for grazing. Likewise, leaf litter (L) rich in humus and organic matter is found in abundance on the floor of temperate forests and therefore, was used in the present study. Manure was employed prior to seedling transplantation during first year and before the onset of new sprouts after winter during second and third year. Experimental set up for manure treatments and plots is presented in Table 1.

For the study, seedlings of $A$. archangelica were raised through seeds in polyhouse using Styrofoam seedling containers having sand, soil and leaf litter in 1:1:1 proportion. Raised seedlings of different age (two, three and four months) were transplanted in experimental plots at TN and PV using aforesaid treatments (Table 1) during the month of May 2003. Each treatment was examined for plant growth parameters, i.e. economic yield of the plants at the end of growing season (OctoberNovember) for three consecutive years. In addition, cultural practices, i.e. weed removing and irrigation etc., were performed whenever felt necessary during observation period.

\section{Economic yield of plants at different altitudes}

To observe economic yield of the plants, underground part of five plants from each treatment were uprooted at the end of growing season in 2005. These plants were brought to laboratory, washed with running water; surface dried and fresh weight was recorded. Further, all samples were dried at 80 ${ }^{\circ} \mathrm{C}$ for 24 hours or until constant weight (at 40 ${ }^{\circ} \mathrm{C}$ in case of seedlings) to measure dry weight (g/plant). Variation in economic yield during three consecutive years among different treatments was analyzed using ANOVA.

\section{Economics of cultivation}

To calculate commercial viability of cultivation, the total investment on infrastructure development, land preparation, manure cost, irrigation facilities, harvesting and post-harvesting cost etc. was calculated for a three-year period, and the total cost of cultivation and post-harvesting was calculated for one hectare of land as described earlier by Vashistha et al. (2007). For the estimation of projected yield, the plant density $(50,000)$ in a hectare of land was multiplied with average yield by the end of the third year for each treatment. Considering the survival percentage of plants, actual yield was also calculated.

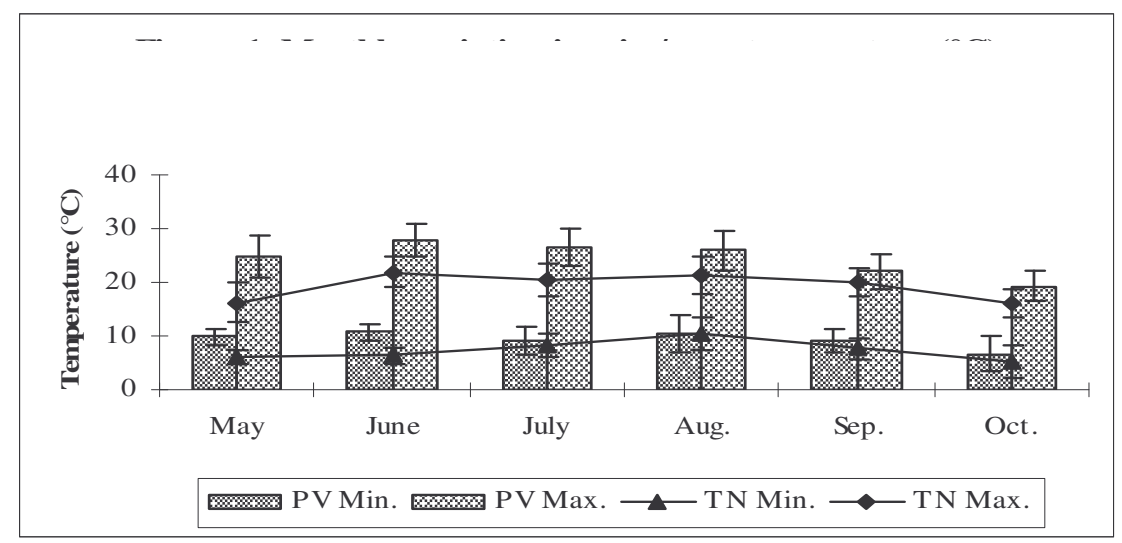

Figure 1: Monthly variation in $\min . / \max$. temperature $\left({ }^{\circ} \mathrm{C}\right)$ at two nurseries. 


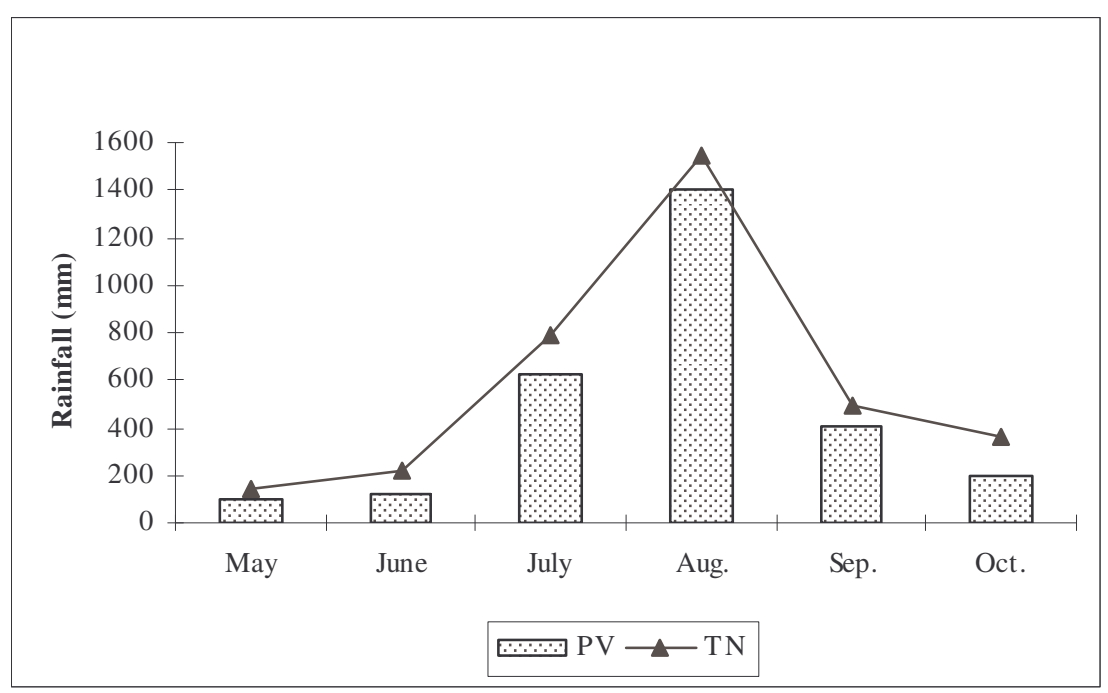

Figure 2: Monthly variation in rainfall (mm) at two nurseries.

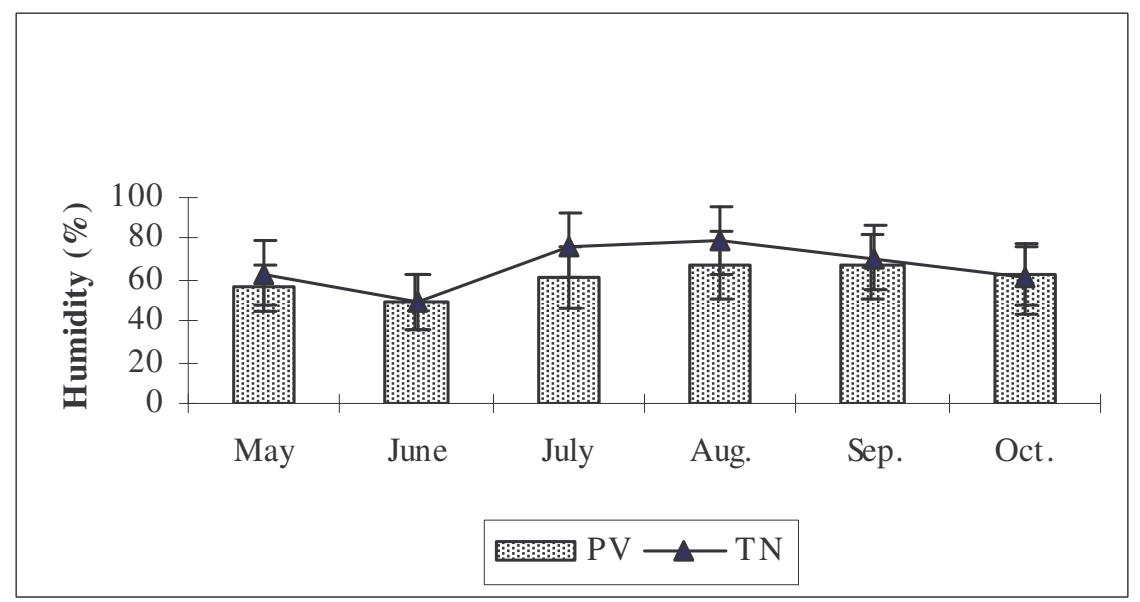

Figure 2: Monthly variation in humidity (\%) at two nurseries.

Table 1: Experimental plots with different treatments.

\begin{tabular}{|c|c|c|c|}
\hline S.N. & Treatments & Manure Used & Manure dose/plot \\
\hline 1. & Control & Ordinary site soil & - \\
\hline 2. & BM1 & Buffalo manure & $1 \mathrm{~kg} \mathrm{~m}^{-2}$ year $^{-1}$ \\
\hline 3. & BM2 & Buffalo manure & $2 \mathrm{~kg} \mathrm{~m}^{-2}$ year $^{-1}$ \\
\hline 4. & L1 & Leaf Litter & $1 \mathrm{~kg} \mathrm{~m}^{-2}$ year $^{-1}$ \\
\hline 5. & $\mathrm{~L} 2$ & Leaf Litter & $2 \mathrm{~kg} \mathrm{~m}^{-2}$ year $^{-1}$ \\
\hline \multicolumn{4}{|c|}{ Earthing up experiments } \\
\hline 1. & Raise bed with horizontal bunds (HB) & Litter & $1 \mathrm{~kg} \mathrm{~m}^{-2}$ year $^{-1}$ \\
\hline 2. & Raise bed with vertical bund (VB) & Litter & $1 \mathrm{~kg} \mathrm{~m}^{-2}$ year $^{-1}$ \\
\hline 3. & Polyhouse beds (PB) & Manure and Litter & $0.5 \mathrm{~kg} \mathrm{~m}^{-2}$ year $^{-1}(1: 1)$ \\
\hline
\end{tabular}


Commercial viability of the cultivation was calculated on the basis of expenditure on cultivation during three years for $A$. archangelica and considering present market rate of Rs. $150 / \mathrm{kg}$ prevailing in market of the region.

\section{RESULTS}

Observations at PV site reveal that economic yield of crops raised from 2 months old seedlings (60 days) was a minimum in control set. It varied with treatments and with increased manure doses. In BM1 yield was $1.42 \mathrm{~g} /$ plant and it increased further in L1 treatment $(3.00 \mathrm{~g} /$ plant $)$ at the end of first growth season. Under PB condition, yield was comparatively higher, i.e. $3.67 \mathrm{~g} /$ plant after first growth season, $17.70 \mathrm{~g} /$ plant after second growth season and $19.33 \mathrm{~g} / \mathrm{plant}$ after third growth season with nearly $19 \%$ increase in third growth season as compared to first growth season. During the first growth season, there was no significant improvement irrespective of any treatments. However, yield significantly improved during second growth season and third growth season on the basis of ANOVA. Compared to control, yield under PB condition only improved significantly during the observation period of three year $(\mathrm{LSD}=2.96 ; \mathrm{P}<0.05)$ (Table 2$)$.

Plants raised through the transplantation of three months old (90 days) seedlings also showed minimum yield in control condition during the observation period (three years) which increased further with the addition of manure and litter. The yield was $3.56 \mathrm{~g} / \mathrm{plant}$ (L1) to $3.89 \mathrm{~g} / \mathrm{plant}$ (L2) in litter treatments and $1.58 \mathrm{~g} / \mathrm{plant}$ (BM1) to $2.45 \mathrm{~g} /$ plant (BM2) BM manure. HB conditions also showed superiority over VB and shade conditions after the first growth season. Comparatively, yield was higher than the crops raised through 60 days old seedlings. Overall, yield was highest under PB condition throughout the three growth seasons and there was an increase of nearly $13 \%$ in yield at the end of the third growth season in comparison to the second growth season. However, yield improved in various treatments significantly only after second growth season and compared to control variation was significant for $\mathrm{PB}, \mathrm{L} 2$ and $\mathrm{HB}$ treatments during first growth season, for $\mathrm{PB}$, L2, $\mathrm{HB}$ and VB treatments during second growth season and besides PB, L2, HB treatments, shade condition also improved yield significantly (Table 2).

Similar trend as in 60 and 90 days old seedlings was noted for 4 months old (120 days) seedlings, as control set showed minimum yield in comparison to manure and litter treatments. However, yield was comparatively higher and it was maximum (4.45 g/plant) under PB condition at the end of first growth season. By the end of second growth season, yield inside $\mathrm{PB}$ reached up to $21.38 \mathrm{~g} /$ plant and further increment of nearly $6.52 \%$ was noted at the end of third growth season. On the basis of ANOVA, variation in yield was found significant during second growth season and third growth season in different treatments. Compared to control, variation in yield was found significant in litter and PB treatments at the end of second growth season and only for PB at the end of third growth season (Table 2). The above observations reveal that crop raised from two months old seedlings had minimum yield in comparison to 90 and 120 days old seedlings. With the exception of PB condition, there was no or little variation in yield obtained from the transplantation of three and four month's old seedlings at temperate site, PV.

In alpine environment, due to adverse climatic conditions plant growth is very slow and we found similar observations during the course of this study. A. archangelica seedlings showed comparatively slow growth and hence the yield as comparison to temperate site PV. Though the trend of response under various treatments and bed conditions was similar to $\mathrm{PV}$, yield was at lower order in TN site. Compared to maximum yield of $19.3 \mathrm{~g} /$ plant under PB at PV, it was only $5.62 \mathrm{~g} /$ plant at TN after the $3^{\text {rd }}$ year of growth of two months old seedlings and there was significant variation in yield of various treatments during all three growth seasons on the basis of ANOVA. Furthermore, PB had significant variation $(\mathrm{LSD}=0.14,1.92$ and $1.67 ; \mathrm{P}<$ 0.05 ) in yield as compared to control in first, second and third year respectively (Table 2).

Rhizome yield from the plants raised from three months old seedlings of $A$. archangelica was lowest in nature (slope of alpine garden) followed by plain beds (control) and maximum economic yield of $1.78 \mathrm{~g} /$ plant was recorded in $\mathrm{HB}$ at the end 
Table 2: Rhizome biomass of different aged transplanted seedlings of Angelica archangelica in $\mathrm{PV}$ and TN sites.

\begin{tabular}{|c|c|c|c|c|c|c|c|c|c|}
\hline \multirow[t]{2}{*}{ Treatment } & \multicolumn{3}{|c|}{60 days dry weight (g) } & \multicolumn{3}{|c|}{90 days dry weight (g) } & \multicolumn{3}{|c|}{120 days dry weight (g) } \\
\hline & $I^{\text {st }}$ year & II $^{\text {nd }}$ year & III $^{\text {rd }}$ year & I $^{\text {st }}$ year & II $^{\text {nd }}$ year & III $^{\text {rd }}$ year & $I^{\text {st }}$ year & II $^{\text {nd }}$ year & III $^{\text {rd }}$ year \\
\hline \multicolumn{10}{|c|}{ Temperate site (PV) } \\
\hline Control & $1.2 \pm 0.08$ & $1.74 \pm 0.83$ & $2.493 \pm 0.49$ & $1.53 \pm 0.21$ & $1.96 \pm 0.70$ & $3.19 \pm 1.09$ & $1.93 \pm 0.49$ & $2.17 \pm 0.44$ & $3.41 \pm 0.71$ \\
\hline L1 & $3.00 \pm 1.65$ & $3.59 \pm 0.79$ & $4.08 \pm 0.88$ & $3.56 \pm 2.61$ & $3.90 \pm 1.11$ & $4.54 \pm 0.97$ & $4.19 \pm 2.14 *$ & $4.30 \pm 0.64$ & $5.20 \pm 1.43$ \\
\hline BM1 & $1.42 \pm 0.24$ & $1.88 \pm 0.70$ & $3.22 \pm 0.16$ & $1.58 \pm 0.34$ & $2.11 \pm 0.70$ & $3.84 \pm 0.64$ & $2.00 \pm 0.36$ & $2.25 \pm 0.65$ & $4.14 \pm 0.38$ \\
\hline L2 & - & - & - & $3.89 \pm 2.66^{*}$ & $4.88 \pm 1.03 *$ & $6.22 \pm 1.51 *$ & - & - & - \\
\hline BM2 & - & - & - & $2.45 \pm 0.82$ & $3.48 \pm 0.68$ & $4.39 \pm 0.70$ & - & - & - \\
\hline $\mathrm{PB}$ & $3.67 \pm 1.52 *$ & $17.70 \pm 4.40 *$ & $19.33 \pm 3.29 *$ & $4.15 \pm 1.66 *$ & $18.65 \pm 4.93 *$ & $21.06 \pm 5.06^{*}$ & $4.45 \pm 1.74 *$ & $20.07 \pm 3.01 *$ & $21.38 \pm 5.18 *$ \\
\hline HB & - & - & - & $3.95 \pm 1.05 *$ & $4.95 \pm 0.30 *$ & $6.26 \pm 0.51 *$ & - & - & - \\
\hline VB & - & - & - & $1.96 \pm 0.47$ & $4.37 \pm 0.53 *$ & $5.72 \pm 1.08$ & - & - & - \\
\hline Shade & - & - & - & $1.90 \pm 0.30$ & $2.17 \pm 0.17$ & $6.93 \pm 2.34 *$ & - & - & - \\
\hline Spacing & - & - & - & $3.33 \pm 2.22$ & $3.78 \pm 1.13$ & $4.43 \pm 0.99$ & - & - & - \\
\hline F value & 2.96 & $33.50 *$ & $65.57 *$ & 1.20 & $24.36^{*}$ & $20.85^{*}$ & 2.88 & $88.81 *$ & $30.06 *$ \\
\hline $\begin{array}{l}\text { LSD } \\
(\mathrm{P}<0.05)\end{array}$ & 1.73 & 3.37 & 2.52 & 2.23 & 2.39 & 2.73 & 1.21 & 2.27 & 3.98 \\
\hline \multicolumn{10}{|c|}{ Alpine site (TN) } \\
\hline Control & $0.17 \pm 0.05$ & $0.54 \pm 0.14$ & $0.66 \pm 0.14$ & $0.20 \pm 0.07$ & $0.63 \pm 0.19$ & $0.82 \pm 0.15$ & $0.34 \pm 0.17$ & $0.82 \pm 0.15$ & $0.96 \pm 0.26$ \\
\hline L1 & $0.51 \pm 0.30 *$ & $1.09 \pm 0.79$ & $1.39 \pm 0.53$ & $0.58 \pm 0.28^{*}$ & $1.26 \pm 0.64$ & $1.56 \pm 0.38$ & $0.69 \pm 0.33$ & $1.29 \pm 0.71$ & $2.23 \pm 0.92$ \\
\hline BM1 & $0.25 \pm 0.41$ & $0.84 \pm 0.32$ & $1.05 \pm 0.27$ & $0.47 \pm 0.19$ & $0.95 \pm 0.28$ & $1.19 \pm 0.18$ & $0.64 \pm 0.10$ & $1.17 \pm 0.62$ & $1.93 \pm 1.34$ \\
\hline PB & $0.61 \pm 0.16^{*}$ & $4.13 \pm 2.48 *$ & $5.62 \pm 2.20 *$ & $0.68 \pm 0.19 *$ & $4.30 \pm 2.36^{*}$ & $6.07 \pm 1.60 *$ & $1.06 \pm 0.47 *$ & $4.51 \pm 2.17 *$ & $6.86 \pm 0.89 *$ \\
\hline HB & - & - & - & $1.78 \pm 0.33 *$ & $2.91 \pm 0.27 *$ & $3.39 \pm 1.03 *$ & - & - & - \\
\hline VB & - & - & - & $1.20 \pm 0.36^{*}$ & $2.26 \pm 0.38 *$ & $3.27 \pm 0.59 *$ & - & - & - \\
\hline Open Slope & - & - & - & $0.19 \pm 0.07$ & $0.56 \pm 0.10$ & $0.87 \pm 0.12$ & - & - & - \\
\hline F value & $5.00 *$ & $4.84 *$ & $12.34 *$ & $20.34 *$ & $6.40 *$ & $13.09 *$ & 3.14 & $6.33 *$ & $23.80 *$ \\
\hline $\begin{array}{l}\text { LSD } \\
(\mathrm{P}<0.05)\end{array}$ & 0.14 & 1.92 & 1.67 & 0.28 & 1.33 & 1.21 & 0.41 & 1.72 & 1.32 \\
\hline
\end{tabular}

of the first growth season. By the end of the second growth season, economic yield remain lowest in nature while PB condition gave maximum yield. There was nearly $42 \%$ increment in yield inside $\mathrm{PB}$ at the end of third growth season in comparison to second growth season. Variation was found significant for $\mathrm{VB}, \mathrm{HB}, \mathrm{L} 1$ and $\mathrm{PB}$ treatments during the first growth season as compared to control, while, during the second and third growth seasons, variation was significant for HB, VB and PB treatments (Table 2). Overall, compared to temperate site, PV, yield was again at lower order in site TN. Similar trends were also observed for the crop raised through four months (120 days) old seedling with no or little variation in yield than that of the crop raised through three month seedling. Furthermore, variation was found significant after second growth season onwards and only PB condition showed significant variation in yield for three years as compared to control (Table 2).

\section{Economics of cultivation/ commercial viability per hectare}

Projected benefit of A. archangelica in temperate site (PV) by transplanting two, three and four months old seedlings under various treatments is presented in Table 3. It was accounted Rs.10,480 in L1 and Rs 120,205 in PB. However, on the basis of plant survival actual profit was recorded Rs. 3,340 in L1, Rs. 96,037 in PB after third growth season harvesting by the crop raised from two months old seedlings. Projected profit through the transplantation of three months old seedlings was nearly $25 \%$ (L1) and $10 \%$ (PB) higher than 60 days old seedling raised crop and the actual profit was recorded maximum Rs $1,14,746.5$ in PB after the third year. Likewise, projected yield of the crops raised from 120 days old seedlings was calculated Rs. 6,655 in control, Rs. 18,880 in L1, Rs. 1,630 in BM1, Rs. $1,35,580$ in PB. However, on the basis of plant survival by the end of the third year, maximum actual profit was recorded Rs 1,16,866.0 in PB less than three months old seedling raised crop and 
Table 3: Commercial viability of Angelica archangelica crop in temperate site, $\mathrm{PV}$ (after III ${ }^{\text {rd }}$ year).

\begin{tabular}{lccccccc}
\hline \multicolumn{7}{c}{ Crop from 2 months old seedlings } \\
\hline Treatments & $\begin{array}{c}\text { Cultivation } \\
\text { cost / ha } \\
\text { (in Rs) }\end{array}$ & $\begin{array}{c}\text { Projected } \\
\text { Production } \\
\text { (in kg) }\end{array}$ & $\begin{array}{c}\text { Projected } \\
\text { Value } \\
\text { Rs 150/kg }\end{array}$ & $\begin{array}{c}\text { Projected } \\
\text { benefit } \\
\text { (in Rs) }\end{array}$ & $\begin{array}{c}\text { Actual } \\
\text { Production } \\
\text { (in kg) }\end{array}$ & $\begin{array}{c}\text { Actual Value } \\
\text { Rs 150/kg }\end{array}$ & $\begin{array}{c}\text { Actual } \\
\text { Benefit } \\
\text { (in Rs) }\end{array}$ \\
\hline Control & 18,920 & 124.50 & 18,675 & -245 & 72.62 & 10,893 & -8027 \\
L1 & 20,120 & 204.00 & 30,600 & 10,480 & 156.40 & 23,460 & 3,340 \\
BM1 & 29,420 & 161.00 & 24,150 & -5270 & 118.06 & 17,709 & -11711 \\
PB & 24,770 & 966.50 & 144975 & 120205 & 805.38 & 120807 & 96,037 \\
\hline \multicolumn{7}{c}{ Crop from 3 months old seedlings } \\
Control & 18,920 & 159.50 & 23,925 & 5,005 & 106.33 & $15,949.5$ & -2970.5 \\
L1 & 20,120 & 227.00 & 34,050 & 13,930 & 185.39 & $27,808.5$ & 7688.5 \\
BM1 & 29,420 & 192.00 & 28,800 & -620 & 147.20 & 22,080 & -7340 \\
L2 & 21,320 & 311.00 & 46,650 & 25,330 & 269.54 & 40,431 & 19,111 \\
BM2 & 39,920 & 219.50 & 32,925 & -6995 & 186.57 & 27985.5 & -11934.5 \\
PB & 24,770 & 1053.00 & 157950 & 133180 & 930.11 & $13,9516.5$ & 114746.5 \\
HB & 20,120 & 313.00 & 46,950 & 26,830 & 255.62 & 38,343 & 18,223 \\
VB & 20,120 & 286.00 & 42,900 & 22,780 & 224.02 & 33,603 & 13,483 \\
Shade & 20,120 & 346.50 & 51,975 & 31,855 & 227.20 & 34,080 & 13,960 \\
\hline \multicolumn{7}{c}{ Crop from 4 months old seedlings } \\
\hline Control & 18,920 & 170.50 & 25,575 & 66,55 & 116.50 & 17,475 & -1445 \\
L1 & 20,120 & 260.00 & 39,000 & 18,880 & 216.65 & 32497.5 & 12377.5 \\
BM1 & 29,420 & 207.00 & 31,050 & 1,630 & 158.70 & 23,805 & -5615 \\
PB & 24,770 & 1069.00 & 160350 & 135580 & 944.24 & 141636 & 116866 \\
\hline \multicolumn{7}{c}{}
\end{tabular}

minimum Rs. $12,377.5$ in L1 after third growth season harvesting (Table 3). BM treatments along with control were not found economically viable treatments as the values were recorded in negative for actual benefits for all aged seedlings. Observations suggest implementation of leaf litter and polyhouse conditions for the economically viable crop of the species.

Likewise, projected benefit of $A$. archangelica in alpine site (TN) by transplanting two months old seedlings was calculated maximum of Rs. 17,380 in PB while considering low rate of plant survival, actual profit was recorded only Rs 4030 far below than same condition at PV site. Projected profit in A. archangelica through the transplantation of three months old seedlings was observed Rs. 20,755 in PB, Rs. 5,305 in HB, and Rs. 4,405 in VB while actual benefit was accounted maximum of Rs 9,373 in $\mathrm{PB}$ condition. Likewise, projected and actual profit of the crops raised from four months old seedlings was Rs 26,680 and Rs $18,230.5$ only in PB condition with $50 \%$ increment than the crop raised from three months old seedlings (Table 4). Overall, results reveal that natural site (alpine) was far more substandard for the cultivation as compared to temperate site in the case of $A$. archangelica.

\section{DISCUSSION}

The ability to tolerate the surrounding environmental conditions is an essential element to the survival. Due to adverse environment, alpine plant species are habitat specific and flourish well only within a narrow range of environment. They have specialized adaptation to a specific set of environment and this means they are very susceptible to all sort of environmental changes (Körner, 1999). Therefore, identification of suitable location is prerequisite for the successful domestication and economically viable cultivation of these species.

Transplantation of smaller size of seedlings caused mortality (Douglas, 1995) and maximum plant mortality after transplantation was noted in younger and smaller seedling (60 days old) of $A$. archangelica at both sites under all treatments. Earlier, Chauhan and Nautiyal (2005) and Vashistha et al. (2007) 
Table 4: Commercial viability of Angelica archangelica crop in alpine site, TN (after III ${ }^{\text {rd }}$ year).

\begin{tabular}{|c|c|c|c|c|c|c|c|}
\hline \multicolumn{8}{|c|}{ Crop from 2 months old seedlings } \\
\hline Treatments & $\begin{array}{c}\text { Cultivation } \\
\text { cost/ ha } \\
\text { (in Rs) }\end{array}$ & $\begin{array}{l}\text { Projected } \\
\text { Production } \\
\text { (in kg) }\end{array}$ & $\begin{array}{c}\text { Projected } \\
\text { Value } \\
\text { at Rs 150/kg }\end{array}$ & $\begin{array}{c}\text { Projected } \\
\text { benefit } \\
\text { (in Rs) }\end{array}$ & $\begin{array}{c}\text { Actual } \\
\text { Production } \\
\text { (in kg) }\end{array}$ & $\begin{array}{c}\text { Actual } \\
\text { Value } \\
\text { at Rs 150/kg }\end{array}$ & $\begin{array}{l}\text { Actual } \\
\text { benefit } \\
\text { (in Rs) }\end{array}$ \\
\hline Control & 18,920 & 33.00 & 4,950 & -13970 & 9.90 & 1,485 & -17435 \\
\hline L1 & 20,120 & 69.50 & 10,425 & -9695 & 45.17 & $67,75.5$ & -13344.5 \\
\hline BM1 & 29,420 & 52.50 & 7,875 & -21545 & 30.62 & 4,593 & -24827 \\
\hline PB & 24,770 & 281.00 & 42,150 & 17,380 & 192.00 & 28,800 & 4,030 \\
\hline \multicolumn{8}{|c|}{ Crop from 3 months old seedlings } \\
\hline Control & 18,920 & 41.00 & 6,150 & -12770 & 19.13 & $2,869.5$ & -16050.5 \\
\hline L1 & 20,120 & 78.00 & 11,700 & -8420 & 57.19 & $8,578.5$ & -11541.5 \\
\hline BM1 & 29,420 & 59.50 & 8,925 & -20495 & 40.65 & $6,097.5$ & -23322.5 \\
\hline PB & 24,770 & 303.50 & 45,525 & 20,755 & 227.62 & 34,143 & 9,373 \\
\hline $\mathrm{HB}$ & 20,120 & 169.50 & 25,425 & 5,305 & 115.81 & $17,371.5$ & -2748.5 \\
\hline VB & 20,120 & 163.50 & 24,525 & 4,405 & 106.27 & $15,940.5$ & -4179.5 \\
\hline Natural Slope & 18,920 & 43.50 & 6,525 & -12395 & 18.84 & 2,826 & -16094 \\
\hline \multicolumn{8}{|c|}{ Crop from 4 months old seedlings } \\
\hline Control & 18920 & 48.00 & 7200 & -11720 & 23.19 & 3478.5 & -15441.5 \\
\hline L1 & 20120 & 111.50 & 16725 & -3395 & 81.67 & 12250.5 & -7869.5 \\
\hline BM1 & 29420 & 96.50 & 14475 & -14945 & 65.55 & 9832.5 & -19587.5 \\
\hline PB & 24770 & 343.00 & 51450 & 26680 & 286.67 & 43000.5 & 18230.5 \\
\hline
\end{tabular}

have also noted similar observations during the domestication of Nardostachys jatamansi and Angelica glauca. Contrary to this, larger size seedlings ( 3 and 4 months old seedlings in this case) showed better ability to survive, as they are more competitive and showed better ability to tolerate stress conditions. Survival percentage was almost similar in 3 and 4 months old seedlings. Therefore, seedlings of age $>90$ days should be transplanted to reduce mortality. Further, survival of transplanted seedlings of all three age group improved second year onwards especially at the temperate site probably due acclimatization. However, continuous seedling mortality at TN may be due to harsh environmental conditions, i.e. soil frost activities (Bliss, 1985) as water scarcity may cause mortality of planted material. Observations also revealed that survival percentage improved with the addition of manure and litter at both sites. Addition of litter and manure increased moisture-retaining capacity of soil and protect plants from drought, a key mortality factor (Bonde, 1968; Bell and Bliss, 1980). Cultural practices may further improved survival (Manjkhola and Dhar, 2002).

The concept of organic farming is gaining popularity and in fact, hill people still rely on organic manure for their agriculture.
During the course of present observations, economic yield was enhanced by the addition of manure and litter and temperate site had superiority over alpine site. This could be due to the supply of essential mineral nutrients, proper aeration and availability of moisture for longer period which is necessary for better growth and development. It also improved microbial properties of the soil and thereby its productivity. Similar observations have also been made earlier (Ramamurthy et al., 1998; Sharma, 2002). Chauhan and Bhatt (2000) suggested addition of 5-10 tons/ha of farm yard manure (FYM) to resolve nutritional problems of various hill crops and deteriorating physical condition of soil. Chauhan and Nautiyal (2005) reported increased economic yield with the addition of farm yard manure (FYM) in N. jatamansi. Comparative yield trails at temperate and alpine sites were earlier observed by Vashistha et al. (2007) in A. glauca and they found maximum yield at temperate site, PV. Similar observations were recorded for $A$. archangelica during the course of this study. Higher economic yield at PV could be due to favorable environment, long growth period (April to November) and favorable temperature regimes etc whereas adverse climate, slow plant growth and short growth 
season in alpine may attributed to lower economic yield.

The presence of a cover (polyhouse) above the crop causes a change in the climatic condition such as reduction in radiation and air velocity, raise soil and air temperature and water vapor pressure and stronger fluctuation of $\mathrm{CO}_{2}$ concentration. The humidity of polyhouse is not adversely affected by evaporation resulting in less requirement of water. Each of these changes has its own effect on growth, production and quality of crops (Abraham et al., 2002). It also protects crops from rain, hail, snow and wind especially in alpine region. Plants grown under polyhouse condition at both sites showed much higher economic yield, as compared to open bed conditions supplemented with manure doses. Such increase in productivity of plants may be inferred to promotion of earliness and stretching growth period further (early emergence and late senescence) as compared to open environment where low temperature restricted early growth and frosting caused earlier senescence. Temperature is the most important factor in different phenological phases (Holway and Ward 1965). It was noticed that in both altitudes sprouting took place 15 days earlier and senescence was also delayed by 15 days inside polyhouse in comparison to nursery grown plants. Butola and Badola (2006) and Vashistha et al. (2007) reported polyhouse conditions suitable for higher seedling emergence, growth and survival in Angelica glauca. Likewise, Nautiyal and Purohit (2000) reported many fold increase in yield of Aconitum species under polyhouse condition.

Ridge formation showed beneficial effect on survival of seedlings at TN. Horizontal ridge (ridges across the slopes) showed better survival percentage than vertical ridges (ridges along the slope) as reported earlier (Chauhan and Nautiyal, 2005; Vashistha et al., 2007). Heavy rainfall common in alpine can harm plants by disintegration of roots in plain beds due to water logging as well as permafrost during winter season. Further, soil freezing due to permafrost condition did not take place in ridge condition especially during winter after snowfall. Plants remain above the surface of water and escape from water logging under ridge condition. Thus, it can be concluded from present study that plain beds with manure treatment are appropriate for cultivation purpose at lower altitude in Angelica archangelica. At higher altitude, raised beds (horizontal) with manure treatment are better cultivation conditions.

In general, on the basis of above observation it can be conferred that temperate sites $(2200 \mathrm{~m})$ are suitable for the cultivation of A. archangelica as seedling survival, growth performance and economic yield were better at this site as compared to natural (alpine) site. Yield can further be improved with the addition of manure (leaf litter in particular) and using polyhouse conditions. Climatic conditions of temperate region are also favorable for the plant growth.

\section{ACKNOWLEDGEMENTS}

We are grateful to Prof. A. N. Purohit former Director and Prof. A. R. Nautiyal, Director HAPPRC for providing facilities and encouragement. Financial support from NMPB, Ministry of Health and Family Welfare, Govt. of India, New Delhi is gratefully acknowledged.

\section{REFERENCES}

Abraham M, Padakumari O, Nagalakshmi S, Palanisamy D, Sreenarayan UV. 2002. Energy balance of tomato (Lycopersicum esculentum Mill) in greenhouse. International Conference on Vegetables, November 2002, Banglore, India, p 83.

Anonymous. 1985. The Wealth of India. A dictionary of Indian Raw Materials \& Industrials Products. Vol. 1A (Revised); 275-276.

Bell KL, Bliss LC. 1980. Plant reproduction in a high arctic environment. Arctic and Alpine Research., 12: 1-10.

Bliss LC. 1985. Alpine. In Physiological Ecology of the Northern American Plant Communities, Chabot BF, Mooney HA. (eds). Chapman Hall; 41-65.

Bonde EK. 1968. Survival of seedling of an alpine clover (Trifolium nanum Torr.). Ecology, 49: 1193-1195.

Butola JS, Badola HK. 2006. Assessing seedling emergence, growth and vigour in Angelica glauca Edgew. and Heracleum candicans Wall. under different growing 
media and environments. Journal of NonTimber Forest Products, 13(2):141-153.

Chauhan RS, Nautiyal MC. 2005. Commercial viability of cultivation of an endangered medicinal herb Nardostachys jatamansi at three different agro-climatic zones. Current Science, 89(9):1481-1488.

Chauhan VS. Bhatt JC. 2000. Agriculture in Uttarakhand: From subsistence towards self-sufficiency. In Uttarakhand Statehood: Dimensions of Development, Sati MC, Sati SP (eds). Indus Pub. Co.: New Delhi; 168-180.

Chevallier A. 1996. The Encyclopedia of Medicinal Plants. Dorling Kindersley: London, ISBN 9-780751-303148.

Douglas DA. 1995. Seed germination, seedling demography, and growth of Salix setchellina on glacial river gravel bars in Alaska. Canadian Journal of Botany, 73: 673-679.

Gaur RD. 1999. Flora of the District Garhwal North-West Himalaya (With ethenobotanical notes). Transmedia: Srinagar (Garhwal.), India.

Grieve A. 1984. Modern Herbal. Penguin ISBN 0-14-046-440-9.

Holway JG, Ward RT. 1965. Phenology of alpine plants in Northern Colorado. Ecology, 46: 73.

Körner C. 1999. Alpine Plant Life: Functional Plant Ecology of High Mountain Ecosystem. Springer-Verlag.

Manjkhola S, Dhar U. 2002. Conservation and utilization of Arnebia benthamii (Wall.ex G. Don) Jonston-A high value Himalayan medicinal plant. Current science, 83(4): 484-488.

Nautiyal BP, Prakash V, Chauhan RS, Purohit H, Vashistha R, Nautiyal MC. 2005. Cultivation of Aconitum species. Journal of Tropical Medicinal Plants, 6(2):1932001.

Nautiyal BP, Prakash V, Chauhan RS, Purohit H, Nautiyal MC. 2001. Assessment of germinability, productivity and cost benefit analysis of Picrorhiza kurrooa cultivated at lower altitude. Current Science, 81(5): 579-585.

Nautiyal BP, Prakash V, Chauhan RS, Purohit H, Nautiyal MC. 2003. Germinability, productivity and economical viability of Rheum emodi cultivated at lower altitude. Current Science, 84(2): 143-148.

Nautiyal MC, Nautiyal BP. 2004. Agrotechniques for High Altitude Medicinal and Aromatic Plants. High Altitude Plant Physiology Research Centre and Mahendra Pal Singh Bishen Pal Singh, Dehradun.

Nautiyal MC, Purohit AN. 2000. Cultivation of Himalayan Aconites under polyhouse conditions. Current Science, 78(9): 10621063.

Phillips R, Foy N. 1990. Herbs. Pan. Books Ltd: London, ISBN 0-330-30725-8.

Ramamurthy V, Sharma RK, Kothari RM. 1998. Microbial conservation of LignoCellulosic waste into soil conditioner. In Advances in Biotechnology, Pandey A (ed). Educational Pub.: New Delhi; 433438.

Sarker SD, Nahar L. 2004. Natural medicine: the genus Angelica. Current Med. Chem., 11(11): 1479-1500.

Sharma R. 2002. Aushdhiya Avyam Sugandhiya Paudhon Ki Krishi Technique (Agro-technique of Medicinal \& Aromatic Plants). Daya Publishing House: Delhi.

Vashistha R, Nautiyal BP, Nautiyal MC. 2006. Conservation status and morphological variations between populations of Angelica glauca Edgew. and A. archangelica Linn in Garhwal, Himalaya. Current Science, 91(11): 15371541.

Vashistha R, Nautiyal BP, Nautiyal MC. 2007. Economic viability of cultivation of the Himalayan herb Angelica glauca Edgew. at two different agro-climatic zones. Current Science, 93(8): 11411145. 